\title{
Innovative Exploration and Thinking on Design and Representation Techniques Course
}

\author{
Yifeng Du \\ Zhuhai College of Jinlin University \\ Zhuhai, China 519041
}

\begin{abstract}
Design representation is one of the essential skills of designers, so the course is widely established in related majors and fields. But China's current courses related to majors like art design in higher education can't meet the needs of bringing up modern design talents in the new period. As a starting point, the author analyzed present situation and existing problems of representation techniques course in this paper. According to the need of times development, the author considered and researched creatively and put forward reasonable development planning and direction in the future.
\end{abstract}

Keywords-design representation skills; creativity; research and thinking

\section{INTRODUCTION}

Design representation skills are effective means for designers to express their design concept, design idea, and communicate with the customers. They are essential skills for art and design professionals. They can be implemented by hand-painting and CAD. We only discuss hand-painting here.

Hand-painting design representation can express information of the object of designers completely such as specific image of the project, space division, the form structure, style, form, proportion and scale, color collocation, the selection of materials and furnishings to get the expected design intuitive feelings, which becomes the evaluation and judgment basis for clients. This unique art design language will help designers express their own design ideas and concepts through hand-painted graphic thinking and picture in design process. It is a kind of effective communication tools and means of designers.

\section{CURRENT CONDITIONS AND EXISTING PROBLEMS OF DESIGN REPRESENTATION COURSES}

As a traditional representation skill, hand-printing design representation is a kind of painting established on the basic courses of major design. As design representation is the essential technique of designers, there are many relevant courses in major related to design such as the environmental art design, exhibition design, industrial design, architectural design, etc. Seeing from the current professional courses related to art design in our country's higher education, we can find that even if we have accumulated a lot of experience and methods of teaching and learning in the education teaching for many years, we have formed many old ideas which do not conform to the modern design talents demands, especially the formation of the a single mode of teaching and learning "value performance while lighten thinking, value copy while lighten creation, value result while lighten process". The existing problems in courses of design representation are as follows:

\section{A. The Curriculum Doesn't Match the Whole Course System of Specialty Cultivation Program}

When setting the courses, we are lack of research on similar institutions and experience, we don't have full understanding to the courses and the curriculum design is similar to others. All of these lead to a single course does not match with the whole course system, that the curriculum doesn't match the goal of cultivating practical professional talents, that course features are not distinctive and that the direction of professional training is not clear. We should set the courses according to the talents training goal and the professional training scheme and set courses with target. Thus we will avoid non-standard teaching and casual teaching.

\section{B. The Teaching Methods Are out of Date and the Teaching and Learning Pattern Is Unitary}

In teaching, the teaching goal of teacher is not highlighting. The old contents can't keep up with the times and the theory seriously dislocates with practice. In curriculum of design representation, we attach too much importance to the training of techniques and skills while ignore the guiding of theory and practice. Students just practice drawing lines with their skills, copy and train constantly.

In practical teaching, we only stress students' operational ability while ignore their ability of finding problem, analyzing problem and resolving problem. We should realize that in terms of design skill training, without the guidance of design theory, students will do not know how to start in practice because the improvement of design skills relies on the guidance of design theory and the speculative ability.

\section{Choosing Textbooks and Teaching Materials Randomly}

At present, there are plenty of design representation textbooks in the market but the quality of them is uneven and some textbooks are only medley publications. Colleges and universities are lack of regulation on the choice of teaching material so that the teachers choose teaching material randomly. These books have no practical and referential functions. The textbooks are written informal so they only act 
as auxiliary materials. They don't have the oriental and referential functions of real textbooks.

\section{Lack of Teachers with Comprehensive Skills and Practical Experiences}

Design representation courses are commanding to teachers. They call for high ability of hand-printing and design thinking. Serious lack of such teachers is one reason of the decrease of the quality in teaching.

\section{CREATIVE Thinking ON DESIGN REPRESENTATION COURSES}

\section{A. Optimizing Curriculum System and Highlighting Profession Features}

We should highlight profession features the design representation courses. The courses should concentrate on improving students' innovative and creative ability to strengthen their practical and operational ability. They should be designed to cultivate students' comprehensive ability. We should integrate curriculum resources, optimize the curriculum system and pay attention to its overlapping and bridging between courses. At the same time we should set course according to the goals set by school and the specialty cultivation program and strengthen the practice teaching, put the practice teaching content into the theory teaching and integrate theory with practice.

In addition, every major belongs to the category of design disciplines. The design representation techniques courses in our university involve environmental art design, exhibition design, industrial design, dress design and many other art fields. Along with the deepening reform of teaching, courses between various professionals should be more diversified. Breaking the traditional individual patterns and sharing curriculum resources and information resources to establish a large course platform and realize the sharing of resources and information will inevitably open up a new path for design representation techniques courses.

\section{B. Enriching Teaching Methods and Contents along with the Development of Times}

The design industry is diversified. We should update our ideas along with the development of times, enrich teaching contents and adopt diversified teaching methods to strengthen students' ability of innovation and creation. Thus the works of students will be more multi-variant and original. We can also combine teaching with other new media, break traditional class patterns and add more practice. By reform and practice of the courses to gradually improve teaching methods, we can adopt the follow measures:

We should highlight key points in teaching of design representation courses and take the needs of different levels into consideration. The courses goals should be practical. We should value class teaching and make it more detail and notice the differences of students. We should stress combining theory with practice and extend teaching contents and highlight creative thinking and innovation ability. We should improve courses evaluation system and supervise teaching quality effectively. We should strengthen the publication of textbooks, update textbooks and teaching contents timely to fit the development of times.

\section{Paying Attention to the Cultivation of the Design Thinking and Methods of Students}

In classing teaching, we should change old teaching contents and train students' design thoughts in the process. Traditional design representation courses are mainly teaching painting skills, the modeling of space and picture control. They mainly teach space perspective methods and traditional skills. Only valuing the representation ability is the repetition of basic painting.

We should improve students' design thinking ability in learning process. For example, we can take full advantage of the three views drawing principle of design and turn plane figure into space figure and perspective drawing to cultivate students' spatial thinking ability.

\section{Paying Attention to Training Students' Creative Thinking Ability}

We should change students learning ways, strengthen the learning and training of Innovative thinking ability in learning process. Many students learn hand-painting at beginning by copying outstanding works. The advantage of this approach is learning hand drawing quickly. But there are still some disadvantages: this method will cause the dependence of the students easily that students can't paint without materials. We can change the view, sight, space shape and space style in copying then the students can grasp the skills fast and use them in different perspectives to create works. We can strengthen the design representation ability and inspire the creative thinking ability in this way.

\section{E. Strengthening the Building of Teaching Staff and Improving Teachers' Comprehensive Quality and Self- Cultivation}

The key to improve the teaching quality is the construction of teaching staff. Seeing from the overall quality of teachers for design courses, we can find the teachers cannot satisfy the rapid development of design disciplines. Double-position teachers are needed in colleges and universities. They have rich design experience in the enterprise, strong professional quality and high comprehensive quality. We can introduce such teachers with related methods. We can cooperate with enterprises and invite experts to take a part-time job in colleges, or invite them to give reports regularly to guide teachers and students. We can also establish related research centers and design studio to widen the training thoughts along with requirements of the times. Inviting experts to work in college can improve teachers' comprehensive ability. Teachers can also go out of school to work in enterprises. The key part of related training should be the construction of design representation theory, spread and innovation of design representation skills, research on design representation teaching methods and application of design representation. 


\section{CONCLUSION}

Design representation skills are essential qualities of students and teachers majoring in design. They comprehensively manifest designers' creative thinking and expression ability. Design representation courses bear the tasks of skillful teaching and innovative teaching. So we should emphasis both on basic training and innovation cultivation and value comprehensive development when teaching students. Only in this way can we produce qualified talents for society.

\section{REFERENCES}

[1] Design representation courses Lin Wei, Chemical Industry Press, Sept, 2012

[2] The product design performance techniques. Zhang Huishu, Peking University Press, Aug, 2009

[3] Interior design thinking method and performance techniques, Zhang Xiaoke, Water conservancy and hydropower press, Nov, 2015

[4] Environmental art design representation, Chen Bin, LI Miao, Yin Hang, Chongqing University Press, May, 2010

[5] From interdisciplinary courses to cultivating open and innovative talents - written on the tenth anniversary of information design department, Academy of arts\&design, Tsinghua University, Fu Zhiyong, Decoration, Dec 1, 2014 